\title{
Akwakultura Miejska - model integracji kapitału i wiedzy w przestrzeni komunalnej - Natura 4.0
}

\section{The City Aquaculture - capital and knowledge integration model in municipal development -} Nature 4.0

\section{Streszczenie}

Współpraca przy realizacji Jurassic Salmon, pierwszej na świecie hodowli łososia opartej na źródłach termalnych, stała się inspiracją do rozważań nad przyszłością systemów produkcji żywności. Projekt zrealizowano na podstawie funduszy UE i programu badawczego prowadzonego przez ZUT w Szczecinie, przy proceduralnym wsparciu gmin Karnice i Rewal. Inwestycja funkcjonująca według zasad biobezpieczeństwa, ekologii przemysłowej i efektywności gospodarki zasobami jest przykładem biokultury XXI wieku, która przeniesiona na obszary zurbanizowane może wpisywać się w szeroko rozumianą akwakulturę miejską czy urbanistyczne rolnictwo. To potencjał do wykorzystania przez lokalny samorząd, środowiska naukowe i biznes mogący sprzyjać efektowi synergii w drodze do regeneratywnego planowania i pozytywnego rozwoju.

Słowa kluczowe: biokultura, gospodarka recyrkulacyjna, projektowanie regeneratywne

\begin{abstract}
The cooperation in Jurassic Salmon farm realization, the first in the world salmon fishery based on geothermal resources became an inspiration for future systems of food production deliberation. The project was realized basing on EU funds, research programme led by ZUT in Szczecin with procedural support of Karnice and Rewal communes. The investment powered by renewable energy, works basing on biosafety, industrial ecology rules and resources effectiveness is an example of 21st century bioculture. This one moved to urban areas may comply with broad sense to the city aquaculture or urban agriculture. This is the potential to be used by local self-governments, scientific communities and business and which can favour synergy effect on the way to regenerative design and positive development.
\end{abstract}

Keywords: bioculture, closed loop economy, regenerative design 


\section{WSTĘP}

W dobie czwartej rewolucji przemysłowej dominująca część ludzkiej populacji zamieszkuje obszary zurbanizowane. Rozrastające się miasta sprzyjają często koncentracji kapitału ekonomicznego, umożliwiają rozwój i transfer wiedzy, zmagając się jednocześnie z konsekwencjami utraty kapitału naturalnego. Zarówno rozległe metropolie, jak i małe czy średnie miasteczka, dotknięte są problemami środowiskowymi, cywilizacyjnymi chorobami przestrzeni zbudowanych, odciskając negatywny ślad ekologiczny w środowisku przyrodniczym zarówno na poziomie regionu, jak i w skali globalnej. W celu minimalizacji antropopresji na środowisko trwają dyskusje nad uzdrowieniem metabolizmu miast, szuka się alternatyw zrównoważonego rozwoju w postaci rozwoju pozytywnego. Jest to rozwój promujący gospodarkę recyrkulacyjną, projektowanie regeneratywne, restytucję produktywnych terenów zielonych, komunalnych plantacji leśnych czy kultywację miejskiej agrokultury. Wraz z migracją ludzi z terenów wiejskich do rozrastających się miast pojawiają się idee przenoszenia produkcji rolnej na gęsto zaludnione obszary zurbanizowane. Projektowanie i współpraca przy realizacji farmy Jurassic Salmon w Janowie (woj. Zachodniopomorskie), pierwszej na świecie zamkniętej hodowli łososia w oparciu o źródła geotermalne i autonomiczne systemy recyrkulacji wody (RAS, Recirculation Aquaculture System) stały się inspiracją do rozważań nad przyszłością akwakultury w tym akwakultury miejskiej. Ten rodzaj hodowli uznawany jest za najszybciej rozwijający się sektor produkcji żywności w skali globalnej, oparty na innowacyjnych technologiach wspartych szeroko zakrojonymi programami badawczymi i zainteresowaniem międzynarodowego kapitału inwestycyjnego. Od 2000 roku wzrost produkcji pochodzącej z akwakultury notowany jest na poziomie 7\% rocznie w skali globalnej. Obecnie 50\% światowej konsumpcji ryb i owoców morza pochodzi z kontrolowanych farm hodowlanych ${ }^{1}$. Jednocześnie na przykładzie szlachetnego gatunku ryb dynamika spożycia łososia charakteryzuje się gwałtownym wzrostem w skali globalnej. Jego konsumpcja w 2015 roku wynosiła 1,2 mln ton, natomiast w 2050 roku ma wzrosnąć do poziomu 5 mln ton ${ }^{2}$. Na obszarze Unii Europejskiej szacuje się, że 48\% naturalnych zasobów ryb dotkniętych jest problemem przełowienia i utraty zdolności do regeneracji i odtworzenia witalnej liczebności stad ${ }^{3}$. Z tego powodu Wspólna Polityka Rybacka UE zakłada wspieranie przyjaznych środowisku modeli akwakultury. W porównaniu do tradycyjnych hodowli ryb w otwartych akwenach (np. w fiordach norweskich) farmy lądowe oparte na technologii RAS radykalnie sprzyjają oszczędzaniu zasobów wody, eliminują proces zanieczyszczeń i eutrofizacji szczególnie tak wrażliwych obszarów morskich jak półzamknięty basen Morza Bałtyckiego. Zaplanowane pod jednym dachem farmy rybne zapewniają stabilność i kontrolę środowiska hodowli, utrzymują wysoki poziom biobezpieczeństwa, redukując ryzyko występowania chorób, pojawienia się pasożytów czy drapieżników (np. kormoranów) uszczuplających wielkość hodowlanego stada. Technologie RAS gwarantują stały poziom produkcji (porównywalny ilościowo i jakościowo w cyklu tygodniowym przez cały rok), eliminują ryzyko ucieczki ryb 
czy proceder ich kradzieży powszechnie występujący na terenach otwartych stawów rybnych. Przyszłością RAS są autonomiczne farmy o dużej skali produkcji, oparte o zintegrowane przetwórstwo, miejscowe wytwórnie pasz, rozwój systemów akwaponicznych i hydroponicznego ogrodnictwa ${ }^{4}$. Prowadzi to do tworzenia ekologicznych agroparków - systemów produkcyjno-logistycznych w rodzaju środowiskowych hubów wykorzystujących efekt synergii, zasady zintegrowanego i zrównoważonego łańcucha dostaw, cyrkulacyjnego wykorzystania odpadów i kaskadowej konsumpcji energii w celu wzmocnienia ekologicznej efektywności planowanych inwestycji. Stąd miejskie lokalizacje zintegrowanych farm rybnych i urbanistycznej agrokultury w powiązaniu z procesami rewitalizacji obszarów postindustrialnych (inwestycje typu brownfield i greyfield) stają się ciekawym zagadnieniem badawczym, szczególnie gdy farmy miejskie często związane są z oddolnym ruchem społecznym propagującym produkcję świeżej, lokalnej żywności oraz sieciowy system dystrybucji. Ekologiczne technologie zastosowane w Jurassic Salmon mogą być dobrym przykładem i inspiracją dla realizacji tego typu przedsięwzięć w środowisku zbudowanym, na obszarach miejskich o zróżnicowanych układach funkcjonalnych, niejednorodnej strukturze społecznej czy gęstej, sieciowej infrastrukturze.

\section{FARMA „JURASSIC SALMON” W JANOWIE - STUDIUM PRZYPADKU}

Zainicjowane w 2010 roku przez lokalnych inwestorów przedsięwzięcie zrealizowano w oparciu o fundusze UE w ramach Programu Operacyjnego „Zrównoważony rozwój rybołówstwa i nadbrzeżnych obszarów rybackich 2007-2013” działanie 3.5 Projekty pilotażowe oraz na podstawie programu badawczego „Wykorzystanie technologicznych zasolonych wód geotermalnych do chowu i hodowli ryb" prowadzonego przez Zachodniopomorski Uniwersytet Technologiczny w Szczecinie pod kierunkiem dra hab. inż. Jacka Sadowskiego, przy proceduralnym wsparciu gmin Karnice i Rewal. Analizowane studium przypadku jest inwestycją typu greenfield, zasilaną energią odnawialną. Zaprojektowano farmę funkcjonującą w oparciu o rygorystyczne przepisy biobezpieczeństwa ${ }^{5}$, ekologii przemysłowej, efektywności wykorzystania zasobów i odpowiedzialnej produkcji. To jedyna na świecie hodowla, w której łosoś rozwija się i rośnie w bardzo czystej i bezpiecznej mikrobiologicznie wodzie geotermalnej z okresu Dolnej Jury, oraz trzeci obiekt prowadzący produkcję od ikry do osobnika dorosłego pod jednym dachem ${ }^{6}$.

\subsection{GENEZA PROJEKTU - PROBLEMATYKA EFEKTYWNOŚCI EKOLOGICZNEJ INWESTYCJI}

Plany inwestora, związanego z Trzęsaczem (dawną wioską rybacką z charakterystycznymi ruinami gotyckiego kościoła na klifie środkowego wybrzeża Bałtyku w gminie Rewal) zakładały realizację całorocznego ośrodka wypoczynkowego na terenie zabytkowego zespołu 
pałacowego. Rewitalizacja XVII wiecznego pałacu dla funkcji hotelowej (dawniej ośrodek wypoczynkowy Państwowego Ośrodka Hodowli Zarodowej) miała być poprzedzona realizacją centrum kongresowego z zespołem basenów rekreacyjnych na obrzeżach parku pałacowego. Atrakcją części rozrywkowej miał być akwapark wyposażony w wewnętrzne i zewnętrzne baseny termalne o łącznej powierzchni lustra wody ok. $1500 \mathrm{~m}^{2}$. Analogiczny park wodny zasilany źródłami geotermalnymi (temp. wody ok. $36^{\circ} \mathrm{C}$ ) funkcjonuje w przygranicznym Ahlbecku - $3 \mathrm{~km}$ od Świnoujścia. W sąsiedztwie zespołu pałacowego inwestor wykonał ujęcie wody geotermalnej -Trzęsacz GT-1 o głębokości otworu 1224,5 m p.p.m. oraz o wydajności samowypływu $180 \mathrm{~m}^{3} / \mathrm{h}$ i temperaturze eksploatacyjnej wody $25,4^{\circ} \mathrm{C}^{7}$. Przedsięwzięcie współfinansowane było ze środków NFOŚ, jednakże uzyskane cieplne parametry wody geotermalnej okazały się niższe niż zakładane, choć pozyskane z poziomu wodonośnego Dolnej Jury solanki chlorowo-sodowe posiadają mineralizację na poziomie 13,5 g/l i charakteryzują się pozytywnymi właściwościami dla potrzeb balneologicznych. Jednakże relatywnie niska temperatura wody geotermalnej nie gwarantowała rentowności ekonomicznej planowanych, ciepłych basenów termalnych, które należałoby dodatkowo podgrzewać z użyciem innych źródeł energii. W podobnej sytuacji znalazły się władze samorządowe Lidzbarka Warmińskiego, gdzie temperatura wody pozyskiwanej z odwiertu geotermalnego wynosi $21^{\circ} \mathrm{C}$, co nie powstrzymało realizacji Term Warmińskich i podgrzewania basenów na terenie akwaparku. Inwestor w Trzęsaczu zrewidował plany inwestycyjne i podjął decyzje o innym wykorzystaniu wody geotermalnej. Wstępnie zaplanowano odzysk ciepła dla potrzeb instalacji grzewczej w budynku pałacowym oraz pompowanie wody geotermalnej na rolne działki inwestora położone w Janowie (gmina Karnice), odległe $5 \mathrm{~km}$ od ujęcia wody. Tam już częściowo schłodzona woda geotermalna wykorzystywana jest do procesów technologicznych w hodowli ryb. Inwestycję zrealizowano w oparciu o nowatorską, duńską technologię akwakultury dla zamkniętych farm lądowych z recyrkulacyjnymi systemami obiegu wody (RAS). Dzięki temu woda geotermalna wykorzystywana jest w efektywny sposób nie tylko do celów pozyskiwania energii cieplnej, ale również do zasilania kontrolowanego środowiska ekosystemów hodowli łososia atlantyckiego.

\subsection{EKOSYSTEMY PRZEMYSŁU 4.0 I EWOLUCJA NATURY 4.0 NA PRZYKŁADZIE FARMY JURASSIC SALMON}

Centralnym obiektem na terenie powołanego w 2013 roku Zakładu Chowu i Hodowli Ryb Jurassic Salmon w Janowie jest nowoczesny, kompaktowy budynek produkcyjny farmy o powierzchni użytkowej ok. 9 tys. $\mathrm{m}^{2}$. W skład parterowej hali wchodzi szereg pomieszczeń technicznych, w tym stacje uzdatniania i odżelaziania wody geotermalnej i słodkiej, stacje filtrów, oczyszczalnie ścieków, pomieszczenia denitryfikacji oraz przetwarzania osadów ${ }^{8}$. Zasadniczą kubaturę zajmują wydzielone pomieszczenia z różnej wielkości zbiornikami do hodowli ryb. Cykl produkcyjny trwa 20-22 miesiące, począwszy od fazy inkubacji ikry 
(sprowadzanej drogą lotniczą z Norwegii lub Islandii) poprzez wzrost narybku, wykształcenie smolta aż po fazę chowu dorosłych osobników osiągających wagę handlową 5-6 kg. Budynek funkcjonuje jako rodzaj rozległego, zintegrowanego urządzenia - formy aparatury badawczej monitorującej specyficzne środowisko hodowli łososia atlantyckiego. Zrealizowano sztuczne ekosystemy, rodzaj Natury 4.0, które odzwierciedlają typowe cykle życia ryb, z pięcioma zamkniętymi obiegami wody w dwóch środowiskach: zimnej wody słodkiej oraz ciepłej wody geotermalnej pochodzącej z okresu Jury sprzed 150 milionów lat. Hodowla odbywa się w hali jedynie oświetlanej światłem sztucznym o zmiennym natężeniu, łącznie z podświetleniem wnętrza zbiorników hodowlanych kolorowym światłem LED. Umieszczone w cylindrycznych zbiornikach dysze regulują prędkość i kierunek strumienia wody, w której pod prąd pływają hodowane łososie. Budynek wyposażono w rozbudowywany system BMS (Building Management System) kontrolujący wiele procesów technologicznych, monitorujący sygnały czujników badających temperaturę wody i pomieszczeń produkcyjnych, dozowanie tlenu, stabilność złoża biologicznego, czy stany awaryjne poszczególnych obiegów9 Dla potrzeb realizowanego programu badawczego analizowano parametry jakościowe wody i jej parametry fizykochemiczne, takie jak: poziom pH, zawartość amoniaku, azotynów, azotanów, $\mathrm{CO}_{2}, \mathrm{BZT}_{5}, \mathrm{CHZTcr}$, zawartość fosforanów i fosforu całkowitego, mieszczące się w zakresie tolerancji dla ryb o najwyższych wymaganiach środowiskowych ${ }^{10}$. Wiele rozwiązań automatyki, dozoru czy monitoringu dostosowano do urządzeń mobilnych z aplikacjami powiadamiającymi o stanach awaryjnych personel dyżurujący w cyklu całodobowym. Projekt technologiczny i związana z nim infrastruktura realizowane były w oparciu o system BIM oraz wirtualny model przestrzenny udostępniony w wirtualnej chmurze. Ułatwia to obecnie zarządzanie budynkiem na odległość, przyspiesza serwisowanie i prowadzenie przeglądów co jest cechą charakterystyczną dla inwestycji Przemysłu 4.0 (Industrie 4.0) ${ }^{11}$.

\subsection{MODEL INTEGRACJI KAPITAŁU I WIEDZY - KREOWANIE INNOWACYJNYCH ROZWIAZZAŃ}

Zrealizowany pilotażowy budynek farmy łososia atlantyckiego Jurassic Salmon w Janowie uzyskał dofinansowanie ze środków UE na poziomie $25 \mathrm{mln}$ zł, przy całkowitym koszcie inwestycji wynoszącym ok. $45 \mathrm{mln} z ł^{12}$ [2]. Wkład własny inwestora obejmował realizację rozległej infrastruktury dostarczającej niezbędne media na plac budowy. Działania infrastrukturalne toczyły się na obszarze dwóch sąsiadujących gmin: Rewal i Karnice. Władze samorządowe wsparły inwestycję szczególnie w fazie planistycznej i projektowej. Gmina Rewal udzieliła wsparcia i usprawniła procedury przy realizacji odwiertu geotermalnego i ujęcia wody. Jednym z założeń docelowo była chęć dystrybucji energii cieplnej pochodzącej ze źródeł odnawialnych dla okolicznych ośrodków wypoczynkowych przy pozytywnych parametrach eksploatacyjnych ujęcia. Sprawnie przeprowadzono procedury zezwalające na wykonanie inwestycji liniowych w pasie drogi gminnej, w zakresie infrastruktury wody geotermalnej 
zasilającej i powrotnej oraz przesyłu słodkiej wody pitnej z prywatnych odwiertów inwestora. Pracownicy Urzędu Gminy angażowali się w konstruktywne rozwiązywanie problemów dotyczących procedur środowiskowych (np. operaty wodno-prawne) oraz w mediowanie w sąsiedzkich sporach własnościowych i formalno-prawnych interpretacjach przepisów. Wiejska gmina Karnice sprzyjała inwestycji poprzez wsparcie prac nad miejscowym planem zagospodarowania terenu dla potrzeb agroparku na obszarze ok. $13 \mathrm{~h}$ w okolicach Janowa. Gmina wyraziła zgodę na rozbudowę gminnej sieci wodociągowej w kierunku wsi Janowo, w celu dodatkowego zaopatrzenia farmy w słodką wodę we wstępnej fazie inwestycji. We współpracy ze Starostwem Powiatowym w Gryficach udzielono zgody na przebudowę drogi powiatowej w celu zapewnienia odpowiednich parametrów technicznych dojazdu do farmy i zapewnienia ciągłości dostaw i cyklicznego odbioru gotowych ryb. Zrealizowany program badawczy potwierdził poprawność funkcjonowania wbudowanej pilotażowej instalacji do hodowli ryb. Wody geotermalne stosowane w Jurassic Salmon zintensyfikowały produkcję ryb, skracając cykl hodowli i zwiększając ich odporność na choroby co zmniejszyło wskaźniki śmiertelności w skali stada. W trakcie realizacji inwestycji oprócz specjalistów z Polski w projekcie zaangażowani byli eksperci z Dani, Islandii, Norwegii, Francji, Chile i Indonezji. Obecnie w Zakładzie Chowu i Hodowli Ryb w Janowie pracę znalazło 21 osób. Tygodniowa produkcja ryb ustabilizowała się na poziomie 12-15 ton, ze zdolnością produkcyjną do 20 ton na tydzień. Firma jako pierwsza w kraju uzyskała międzynarodowy certyfikat ASC zrównoważonej hodowli ryb ${ }^{13}$.

Działania Jurassic Salmon i naukowców ZUT w Szczecinie w trakcie realizacji i rozruchu nowoczesnej farmy hodowli ryb w Janowie oraz uzyskane rezultaty przyczyniają się do rozwoju akwakultury zarówno w skali krajowej jak i międzynarodowej. Idea kontrolowanej hodowli jest przykładem biokultury XXI wieku, która przeniesiona na obszary zurbanizowane może wpisywać się w szeroko rozumianą akwakulturę miejską, akwaponikę czy urbanistyczne rolnictwo. Wywoływać to będzie odmienne niż dzisiaj postrzeganie Natury przez mieszkańców miast w niedalekiej przyszłości oraz sprzyjać kreowaniu innowacyjnej gospodarki.

\subsection{WNIOSKI Z REALIZACJI}

Realizacja skomplikowanego technologicznie obiektu oraz złożonego projektu badawczego w nieprzekraczalnych ramach czasowych, wynikających z terminów i procedur finansowania EU, narzuca rygorystyczną dyscyplinę w podejmowaniu decyzji inwestycyjnych. Krótki harmonogram prac projektowych oraz przygotowania i przeprowadzenia budowy farmy wraz z niezbędną infrastrukturą nie pozwalał na przedłużanie procedur administracyjnych, uwikłanie się w prawne spory formalne z nieprzychylnymi sąsiadami czy przestoje w trakcie wykonywania robót budowlanych. W warunkach krajowych wydaje się, że przeprowadzanie tak trudnej inwestycji w krótkim czasie jest łatwiejsze na otwartej przestrzeni wiejskiej niż na gęsto zaludnionych, konfliktogennych obszarach zurbanizowanych. Władze 
samorządowe małych gmin zabiegają o tego typu przedsięwzięcia (przyjazne środowisku, generujące nowe miejsca pracy), stwarzają systemy zachęt i ułatwień proceduralnych wsparcia organizacyjnego w okresie realizacji inwestycji. Jednakże pojawia się wątpliwość dotycząca ekologicznej skuteczności takich działań. Czy nie występuje wówczas efekt pewnego rozproszenia kapitału i utrata potencjału synergii inwestycji realizowanych w formule greenfield w porównaniu z obszarami zurbanizowanymi (o rozbudowanej infrastrukturze instalacyjnej i drogowej) gdzie można realizować inwestycje typu brownfield lub greyfield. Na terenach wiejskich trudniej realizować nowe drogi dojazdowe, trudniej je utrzymywać w okresie zimowym (klasy odśnieżania), kłopotliwe staje się racjonalne uzbrojenie terenu przy dużym rozproszeniu odbiorców. Ze względu na odległości farmy występować będzie utrudniony dostęp ekip serwisowych i ekspertów w porównaniu z lokalizacjami miejskimi (dostępność lotnisk, bazy noclegowej, uczelni i instytutów badawczych).

Faza przygotowania i projektowania inwestycji, przy rozbudowanych procedurach administracyjnych i środowiskowych a jednocześnie przy krótkich i rygorystycznych terminach pozyskiwania środków unijnych wymaga szybkiego i sprawnego podejmowania decyzji zarówno przez inwestora, jak i zespół projektowy. Przeniesienie procesu projektowania do wirtualnej chmury, bieżące (online) raportowanie procesu wprowadzanych zmian funkcjonalnych, technologicznych, instalacyjnych oraz operowanie na modelu 3D planowanej inwestycji znacząco wpłynęło na przyspieszenie procesu decyzyjnego i realizację prac budowlanych. Przewidziane etapowanie inwestycji umożliwiło warunkowy odbiór wcześniej wykonanej wylęgarni łososia i rozpoczęcie hodowli z zachowaniem rygorów biobezpieczeństwa, praktycznie w trakcie trwania budowy. Działanie takie pozwoliło na uruchomienie cyklu hodowli oraz wczesne rozpoczęcie prac naukowo-badawczych, wpisując się w upowszechnianie formuł Przemysłu 4.0. Farma Jurassic Salmon potwierdziła szersze możliwości wykorzystania wód geotermalnych, niż jedynie dla potrzeb energetycznych. Po przeprowadzeniu badań przystosowana i uzdatniona woda jurajska okazała się znakomitym środowiskiem dla hodowli łososia. W porównaniu z powierzchniowymi zasobami wód, stosowanymi przy tradycyjnych farmach hodowlanych, woda geotermalna ze względu na hermetyczność głębokiego, podziemnego złoża pozbawiona jest zanieczyszczeń chemicznych czy niebezpiecznych dla ryb pasożytów. Systemy RAS stosowane na farmie stały się pewnego rodzaju filtrem dla zmineralizowanych wód geotermalnych przy ponownym ich wprowadzaniu do środowiska. Po odzyskaniu energii cieplnej oraz wymieszaniu zasolonej wody termalnej ze słodką wodą w celu stworzenia właściwego środowiska życia dla dorastających łososi, po ponownym oczyszczeniu (poprzez filtry mechaniczne i złoże biologiczne) woda z hodowli powraca do środowiska poprzez system kanałów melioracyjnych, zasilając słono-słodkie jezioro Liwia Łuża. Przedstawione rozwiązanie może być modelowym przykładem kaskadowego wykorzystania energii geotermalnej ale również praktycznego wykorzystania zasobów wody termalnej dla potrzeb hodowli ryb. W takim modelu użycia wody eliminowany jest kosztowny, drugi odwiert zatłaczający schłodzoną wodę geotermalną z powrotem do ziemi. 
Opisana realizacja jest również dowodem, że brak pozytywnych parametrów temperaturowych wody geotermalnej, uzyskanych po faktycznym wykonaniu odwiertu nie musi prowadzić do zaniechania dalszych działań inwestycyjnych. Determinacja inwestora, przy wsparciu środowiska naukowego i lokalnych władz samorządowych wytyczyła ścieżkę dla przeprowadzenia innowacyjnej inwestycji w sektorze produkcji żywności XXI wieku, ukazując metodę ograniczania poziomu ryzyka przy wykonywaniu odwiertów geotermalnych oraz możliwości wykorzystania wód o niskim potencjale energii termalnej. Skojarzenie współczesnej akwakultury z pozyskiwaniem wód geotermalnych otwiera perspektywę realizacji tego typu inwestycji na obszarach zurbanizowanych, wyposażonych w gęstą sieć infrastruktury, dostęp do ośrodków badawczych, centrów logistycznych i przetwórni opierających swą produkcję na zasadzie kaskadowego zużycia energii oraz formułach ekologii przemysłowej.

\section{PODSUMOWANIE}

Produkcja żywności w miastach może przybierać różne formy i skale przestrzenne, tworząc pozytywny wzrost kapitału naturalnego i społecznego w środowisku zbudowanym, kreując kontrolowalną wersję Natury i systemów podtrzymujących życie. Obecne rozwiązania technologiczne i logistyczne umożliwiają rozwój rolnictwa miejskiego, ze szczególnym uwzględnieniem akwakultury czy akwaponiki. Niewątpliwie jest to rozległy obszar potencjalnych badań, prac planistycznych czy analiz ekonomicznych. Czy migracje intensywnej produkcji rolnej na obszary zurbanizowane w XXI wieku mają rację bytu, czy są ekonomicznie uzasadnione pokaże najbliższa przyszłość? Jednakże upowszechnianie agrokultury miejskiej świadczyć będzie o kierunku rozwoju biokultury mieszkańców miast, o skali społecznej inteligencji ekologicznej i charakteru relacji z Naturą, w tym z wysublimowaną Naturą 4.0. To potencjał do wykorzystania przez lokalną społeczność, włodarzy miast, środowiska naukowe i przedstawicieli biznesu mogący sprzyjać efektowi synergii w drodze do regeneratywnego planowania i pozytywnego rozwoju. 


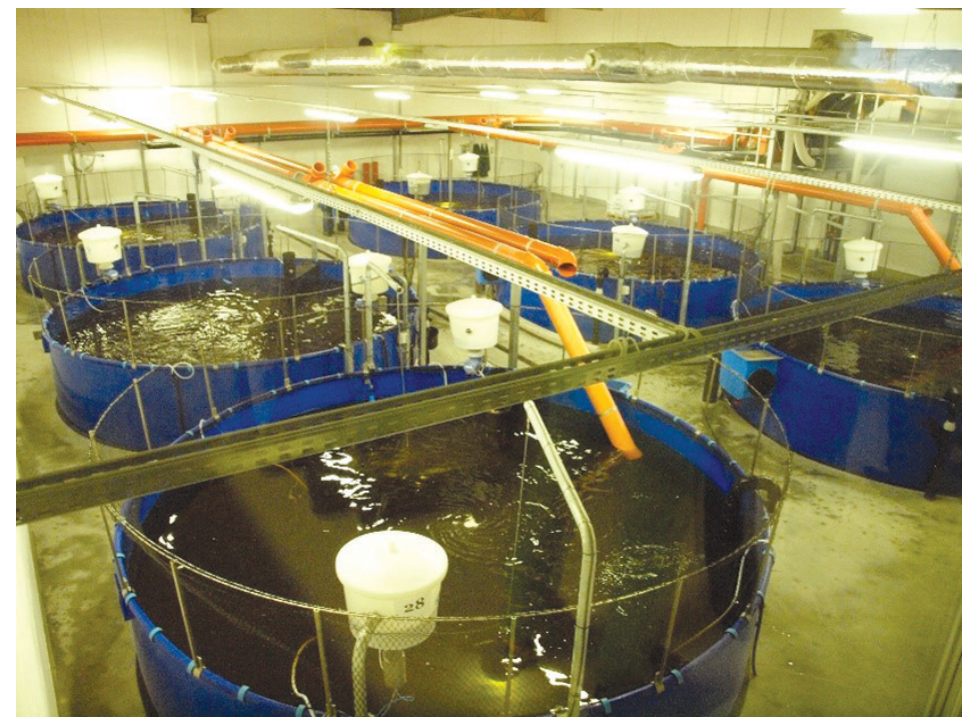

II. 1. Zbiorniki hodowlane łososia o średnicy $5 \mathrm{~m}$ - faza cyklu post-smolt na farmie Jurassic Salmon (fot. L. Świątek)

III. 1. The salmon culture tanks of $5 \mathrm{~m}$ in diameter for post-smolt stage of fish farming in Jurassic Salmon

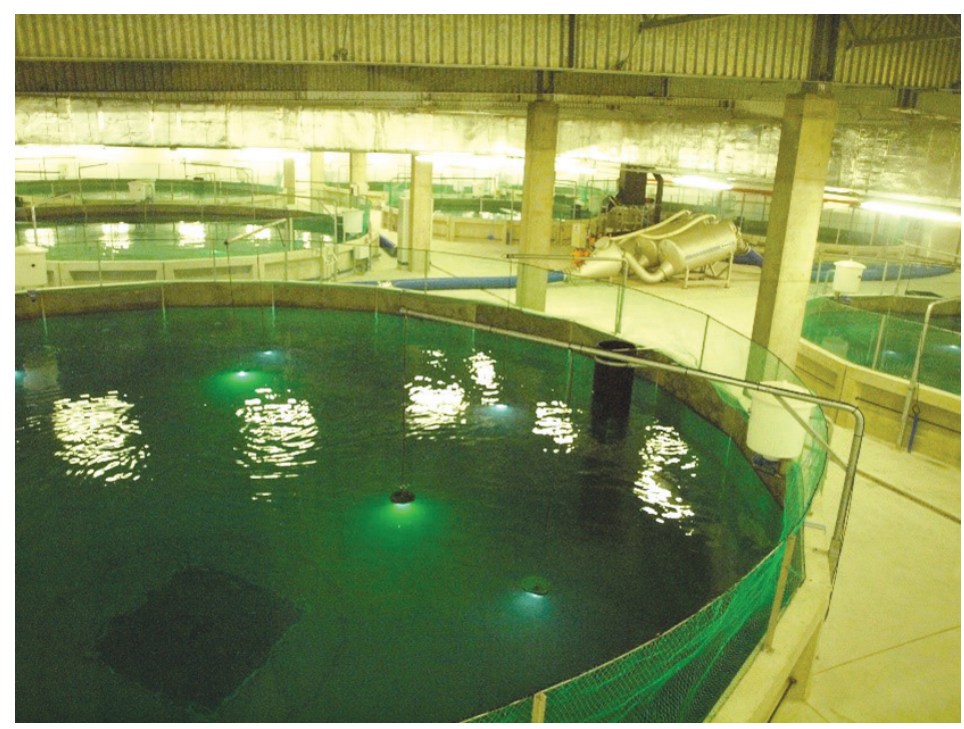

II. 2. Zbiorniki hodowlane łososia o średnicy $12 \mathrm{~m}$ i głębokości do $6 \mathrm{~m}$ - faza tuczu na farmie Jurassic Salmon (fot. L. Świątek)

III. 2. The salmon culture tanks of $12 \mathrm{~m}$ in diameter and $6 \mathrm{~m}$ deep for on-growing stage of fish farming in Jurassic Salmon 


\section{PRZYPISY}

1 J.A. Bregnballe, Guide to Recirculation Aquaculture. An introduction to the new environmentally friendly and highly productive closed fish farming systems, Food and Agriculture Organization of the United Nations (FAO), EUROFISH International Organisation, 2015.

2 Jurassic Salmon, http://jurassicsalmon.pl (dostęp: 12.07.2016).

3 F. Neudörfer, Sustainable Fish Aquaculture, [w:] Submariner Compendium. An Assessment of Innovative and Sustainable Uses of Baltic Marine Resources, A. Schultz-Zehden, M. Matczak (red.), Maritime Institute, Gdańsk 2012, s. 204-230.

4 B.J. Vinci, North American Perspective on Land Based Aquaculture: Past. Present \& Future, The Conservation Fund Freshwater Institute, Shepherdstown 2015.

5 Według Słownika terminologicznego biotechnologii żywności i rolnictwa: „biobezpieczeństwo jest to szeroko opisana ochrona ludzkiego zdrowia i bezpieczeństwa oraz bezpieczeństwa środowiska naturalnego, które mogłoby być narażone poprzez badania lub działalność komercyjną. Głównie związane jest to pracami nad organizmami chorobotwórczymi lub modyfikowanymi genetycznie".

6 Jurassic Salmon, op. cit.

7 M. Kowalski, Land based salmons from Poland. Jurassic Salmon, Szczecin 2015, http:// www.ccb.se (dostęp: 23.01.2016).

8 L. Świątek, Opis do Projektu Budowlanego hali produkcyjnej w Janowie dla firmy Jurassic Salmon, AKCENT Pracownia Projektowa, Szczecin 2013.

9 Ibidem.

${ }^{10} \mathrm{~J}$. Sadowski, The use of saline geothermal water for fish hatching and ongrowing, ZUT, Szczecin 2015.

11 Przemysł 4.0 to zbiorcze pojęcie oznaczającym integrację inteligentnych maszyn, systemów oraz wprowadzanie zmian w procesach produkcyjnych mających w celu zwiększanie wydajności wytwarzania oraz wprowadzenie możliwości elastycznych zmian asortymentu. Przemysł 4.0 charakteryzuje zbieżność świata fizycznego i wirtualnego (cyberprzestrzeni) w postaci systemów cyberfizycznych (CPS), dotyczy nie tylko technologii, ale też nowych sposobów pracy i roli ludzi w przemyśle. Industrie 4.0 (Niemcy) - platforma łącząca przedstawicieli z różnych obszarów, m.in. przemysłu, polityki, biznesu i R\&D, której celem jest standaryzacja i normalizacja, zwiększanie bezpieczeństwa systemów sieciowych, tworzenie ram prawnych, promocja badań i innowacyjności; por. Z. Piątek, Czym jest przemysł 4.0.?, http://przemysl-40.pl (dostęp: 28.03.2017).

12 Jurassic Salmon, op. cit.

13 Ibidem. 


\section{BIBLIOGRAFIA}

Bregnballe J.A., Guide to Recirculation Aquaculture. An introduction to the new environmentally friendly and highly productive closed fish farming systems, Food and Agriculture Organization of the United Nations (FAO), EUROFISH International Organisation, 2015.

Jurassic Salmon, http://jurassicsalmon.pl (dostęp: 12.07.2016).

Kowalski M., Land based salmons from Poland. Jurassic Salmon, Szczecin 2015, http://www. ccb.se (dostęp: 23.01.2016).

Neudörfer F., Sustainable Fish Aquaculture, [w:] Submariner Compendium. An Assessment of Innovative and Sustainable Uses of Baltic Marine Resources, A. Schultz-Zehden, M. Matczak (red.), Maritime Institute, Gdańsk 2012, s. 204-230.

Piątek Z., Czym jest przemysł 4.0.?, http://przemysl-40.pl (dostęp: 28.03.2017).

Sadowski J., The use of saline geothermal water for fish hatching and ongrowing, ZUT, Szczecin 2015.

Słownik terminologiczny biotechnologii żywności i rolnictwa, A. Zaid, H.G. Hughes, E. Porceddu, F. Nicholas (red.), ONZ ds. Wyżywienia i Rolnictwa, 2001.

Świątek L., Opis do Projektu Budowlanego hali produkcyjnej w Janowie dla firmy Jurassic Salmon, AKCENT Pracownia Projektowa, Szczecin 2013.

Vinci B.J., North American Perspective on Land Based Aquaculture: Past. Present \& Future, The Conservation Fund Freshwater Institute, Shepherdstown 2015. 